\title{
ATOMIZED SOCIETY: THE ROLE OF WOMEN AND SOCIAL MEDIA IN CULTIVATING MULTIPOLAR OUTCOME OF GLOBALIZATION
}

\author{
Ach. Fatayillah Mursyidi \\ Gajah Mada University \\ ach.fatayillah@mail.ugm.ac.id
}

\section{ABSTRAK}

Globalisasi seringkali hanya dipandang dari manfaat yang bisa didapatkan dengan menafikkan dampak negatif yang muncul. Artikel ini bertujuan mengkaji dampak multipolar dari globalisasi terutama bagi perempuan sebagai pengguna media sosial melaui wawancara dan observasi atas aktivitas mereka di media sosial. Argument dalam artikel dibangun dari tesis bahwa ide tentang "imagined community" Benedict Anderson dan "conversed community" olehMerlyna Lim tidak lagi cukup untukmenggambarkan kondisi sosial saat ini sehingga perlu istilah baru yaitu "atomized society". Perempuan dan media sosial memiliki peran yang samasama penting dalam membangun jalan bagi masyarakat teratomisasi. LISMA (Lingkar Studi Mahasiswi Muslim Peduli Negeri) di Yogyakarta menunjukkan media sosial menjadikan perempuan sebagai pihak yang rentan terhadap dampak global.

Kata Kunci; Globalisasi, Perempuan, Media Sosial, LISMA

\section{ABSTRACT}

Globalization has been so far understood as a mere global phenomenon that benefits all group of people while its negative effects are commonly ignored. This paper examines multipolar outcome of 
globalization in which women and social media are mostly taking a part. The focus is only on women's role as the dominant users of internet. In building the argument, this paper is started by arguing that the idea of 'imagined community' by Benedict Anderson and 'conversed community' by Merlyna Lim are no longer sufficient to portray the impact on social condition nowadays. Rather than using those terms, another term which is more appropriate to apply is proposed; it is atomized society. In this regard, the role of both women and social media are very significant in paving a way of atomized society. Finally, through an informal interview conducted with some members of LISMA (Lingkar Studi Mahasiswi Muslim Peduli Negeri), a faith-based women community in Yogyakarta, it exemplifies how women are evidently vulnerable to such global effect with the help of social media.

Keywords: Globalization, Women, Social Media, LISMA.

\section{A. Introduction}

The issue of globalization is very attractive subject, specifically for historians, social scientists, and human rights activists. This subject is not only a scientific object but also a reality itself. As the scientific object, this issue has been observed and studied by many scholars and researchers to examine its features and effects. As the real phenomenon, this issue has been experienced by almost entire world population. This is a global phenomenon that brings a broad social consequence. Needless to say that sometimes this issue is also utilized politically to benefit some and harm others. In sum, globalization is doubleedge sword; it can have a positive or negative impact on social relationship. This paper is aimed to trace its negative potency. 
However, it was not exaggerating when the globalization is described very briefly above to start this writing, given that even people in the most interior area today are affected by this process. Academically speaking, Globalization is "the intensification of worldwide social relations which link distant localities in such a way that local happenings are shaped by events occurring many miles away and vice versa" (Giddens, 1990:64). It is a process of interaction among people of different culture, social and economic status, and so on. As the multi-cultural process, it almost unlikely that this does not brings any effect, whether good or bad, on which will be explored more later. Before that, historical background is given shortly.

This is very momentous to re-examine the history of globalization since it was understood today as a western product. Accordingly, this idea was brought by Westerners during the colonization. During the process of colonization, the occupied lands were not only exploited economically but also influenced culturally and morally. The European government did not only employ their army but also let their best missionaries go around the world. This fact is sometimes recognized as imperialism, a new kind or continuation of colonization. There are a lot of hidden motives behind this idea. This perception encourages the people to reject this kind of idea as it perceived of bringing a cultural infiltration of the West.

This negative communal perception of globalism has been attempted to response critically by Amartya Sen (2002: A3). In his article, "How to Judge Globalism", he asserted that the total rejection of globalism will not only ignore the western contribution on science and technology but will also become a fool decision since the globalism content of many benefits. Suggesting the same point, Manuel A. Vasquez and Marie Friedmann Marquardt (2003: 35) in 
their book, Globalizing the Sacred: Religion across the Americas, argued against the commonly negative perception of globalization. They argued that "globalization is not a new phenomenon, for there have been many examples of wideranging translocal dynamics throughout history". They advocated a Scottish sociologist, Roland Robertson, who claims the process of globalization is as old as the rise of world religions by pointing out the role of Buddhism under Ashoka's Empire in India and Confucianism in China during the Han dynasty.

Regardless of whether those theories are correct or not, the globalization was on our hands already. We are supposed not to be away of that actuality. In that sense, the concern of this paper is not to judge which theory is valid and which one is not, but rather to examine its social impact, particularly on faith-based women organizations, by visiting their social media and having an informal interview with some of their members. LISMA is subjected in this paper for two reasons; first, it is a closed organization provided exclusively for Muslimah (Muslim women) meaning that unless you are Muslim and women, you cannot partake in terms of both membership and participation of their agendas and second, it is representing an ideologically globalized organization. It is obviously shown by the way they respond to the global phenomena happening worldwide and the very social media functions for them.

\section{B. Discussion}

\section{The Multipolar Effect of Globalization}

Despite the Sen's and others' attempt of answering the human negative response of globalization, most people still believed that globalization has a certain motive. This 
belief will lead them to the sense of suspicion, distrust, and eventually animosity. Here the process of globalization was seemed contra productive. The fact doesn't fit the main purpose of this idea whatsoever. The globalization is no longer beneficial in terms of bridging the global human relationship and communication. The rise of science only makes the social demarcation plainer by which human are not only divided into two or three boxes but many boxes. The question is how this scientific development as agloriousproduct of globalization turns to be dreadful threat for human unity and prosperity. The following elaboration is provided to answer such intriguing question.

In modern science, several principles and methods are applied to achieve the scientific conclusion. One of the most significant principles is positivism that totally rendered on empirical data and human rationality. This kind of principle defines the human inquiry only to one single conclusion. There is no other alternative option available. This logic is become harmful when applied to social relation where people perceive the others in binarial worldview; good and bad, kind and evil, or true and false. It will eventually create social groupings between 'we' and 'they/others'bordered by a huge segregated wall. The way people perceive the others is no longer through humanitarianparadigm but rather through the identity they belong to; religion, gender, and so on. Human are defined with one only insider and many outsiders based on those identities. Whatever doesn't include in their insider identity should be eliminated and whatever does include should be reinforced. The more those identities are reinforced, the more likely social segregation occur. This is how science play decisive role by digging social hole among human relation.

This kind of segregation has actually been articulated by Samuel Huntington in his book, The Clash of Civilization, 
particularly the years after Cold War ceased as a period he concerned at. He started his theses by exploring four common paradigms accepted by scholars and academicians; one world, two worlds, 184 states, and sheer chaos. In contention to those paradigms, he argued that the first two paradigms are too optimistic while the last two are too pessimistic in the sense of all are overlooking the reality. He refused those four paradigms as they are less realistic and compatible each other. We cannot say that the world is two nations at the same time it is one. Whereas there is always possibility to say that there are a dozens of nationalities (Huntington, 1996: 36).

Huntington (1996: 36) proposed an alternative paradigm by viewing the world in terms of seven or eight civilizations. He argued further that the world in post-Cold War era will neither divided into two opposite positions between the West and the East nor hundreds of positions, but rather into "the Western one and the non-Western many". By implementing this argument, he believed that it will be easier to understand the world and provide guideline for policy makers. He pointed out the important developments occurred after the end of Cold War were compatible with his paradigm; the breakup of Soviet Union and Yugoslavia, the rise of religious fundamentalism, etc.

Regardless of the benefit of Huntington's analysis above in terms of increasing our knowledge, his argument did nothing but supported the segregational effect of globalization, not anymore in bipolar way but, using his own term, in multipolar way. The positivistic paradigm is only one type of elements that make the process of globalization more powerfully divisive. This idea negates the subjectivism and the independency of human since they are only a servant of his object. The object, not human himself, determine the result. Indeed, this idea has been 
criticized for many times, specifically by philosophers of Frankfurt School as one of the six objects of their critics along with post-liberal social integration, ego development, mass media and culture, psychology of social protest, and theory of art.

Inspired by Marxian methodology, Max Horkheimer (known as the pathfinder of this philosophical School) for instance addressed his critics incisively on positivistic ideas as which conservative theories are characterized. Accordingly, those theories are contemplative in the sense that it simply observe and ponder the reality without being able to change it. Furthermore, they might turn to be affirmative when it is constrained to comprehension from which it can used to justify the given data or - to use Heidegger's term - facticity, manipulate the truth and block any attempt to disclose it. Drawn on those potencies, they might be easily utilized to maintain the status quo kept by the person in charge (Horkheimer, 1972: 205-206).

Their critics are seemingly not baseless by considering its strong influence on the New Left Movement all around the world. Inspired by Horkheimer and Marcuse who accused positivism and empiricism as the ideology of stagnancy, in some cases, this movement successfully changed the world order by subverting totalitarian authorities. However, in spite of its gloomy historical background, this positivistic paradigm is still a dominant feature not only in scientific method but also in global worldview.

\section{Women in the Vortex of Globalization}

Notwithstanding the schismaticeffect, comprehension should be done to this discussion by exploring also some opportunities produced by this current epoch of human history with respect to the social role of women before going further toward how this process, so to call it, drive 
human species to what later I called 'atomized society'. A vast production of information has transformed its function as basic necessity as other principle commodities such as food and clothing. The fact that technological equipment is nowadays widely consumed even by people in remote areas attests the argument properly. In sum, some scholars will call it a materialization of information. And as a materialized commodity, it eventually complies with the law of market; the more it is demanded by society, the more it is highly priced.

Interestingly, as the information is being materialized in one side, human being, in other side, is going to be more immaterial. Their physical existence is no longer valued without pocketing meaningful ideas manifested in their verbal languages. It is considerably insufficient to judge people only based on the clothes they wear or on how nice they look like. Instead, their creativity and capacity are far more respected in almost all, if not all, aspects of human activity, from home-based to institution-based activities.

For women as an allegedly often-marginalized community, those two existential processes, both materialization of information and immaterialization of human being respectively, are viewed as beneficial circumstances as identified by an Indonesian feminist Muslim woman, Miranda Risang Ayu in her anthologized article, "Muslimah di Era Globalisasi (Muslim Women in Globalization Era)" (Anshori, et, 1997: 119-120). The first is advantageous in terms of conjuring up the home as the center of social and civilizational life. In Islamic tradition, apart from a fierce debate on, women is always associated with domestic roles. This argumentative provision is applying not only to professional activities but also to religious rituals such as shalat (Islamic five-time daily prayers), which unlike men praying in a mosque, women 
usually perform them in their home. Given these homebased activities, the first process is seemed very helpful, particularly for professional women, to do their works by home. By the appearance of communication technology, along with internet, a globally connected network system, they can access their tasks from home and email it back to their boss immediately when they are done.

In the meantime, in terms of immaterialization of human being, it is useful to encourage women mobilizing their ideas and creativities. Though normally women is weaker physically than men, but no doubt that they are competing with men in intellectual and creative sector. We can easily see this on how the high ranks of educational institution, for example, are dominated mostly by women. Unfortunately, those two opportunities are somehow hindered by textual understanding of Islamic precept. It is argued that women should behave properly and minimize showing themselves up in public spaces in which they can potentially be attractive subject for foreign men. Undoubtedly, this religious understanding plays a significant role in narrowing the scope of women either educational or careeractivity as both are always associated with men areas (Sharma, 1987: 348). Of course, this mencentered religious perspective has been criticized a lot by feminist and even religious scholars themselves but it does not reduce the fact that, in some countryside, it is still appealing.

To enrich Ayu's discussion on those benefits above, it should be taken into account as well as to how those processes are also beneficial for women to mobilize a global women mass or even movement through which their internal solidarity is strengthened. By the help of media, they somehow went further by excluding another element of society as they became more and more exclusive. This is 
what exactly will be addressed through the next section of this paper.

\section{The Roleof Media: a Vehicle to 'Atomized Society'}

As alluded in the beginning of this writing that the process of globalization is inevitable. This is the role of mass media that make it more unlikely to be avoided. Some scholars will argue that this particular age makes the globe smaller. Benedict Anderson (1991: 6), for instance, academically named it with "imagined community" in his magnum opus, Imagined Communities. He strongly argued that "all communities larger than primordial villages of face-to-face contact (and perhaps even these) are imagined". His observation particularly focuses on the effect of media, the newspaper. People can access anything through this media, whether positive or negative contents, whether factual or falsified information, and whether meaningful or meaningless value.

The accessibility of media coupled with the human strong attachment to it inevitably elicits the identity reinforcement. The flow of information provides not only knowledge, but also an awareness of allegedly 'others'. The readers started thinking that there are the lyan(others) somewhere. This lyanis somehow often portrayed by media as totally different, unique, and sometime articulated with negative sense such as heretic, uncivilized, etc. Without further direct clarification, this information is taken for granted and believed by the readers. Not surprisingly, this type of consuming information is the root of religious and ideological fanaticism, one of the most contemporary remarkableproblems faced by almost every nation today.

Media does not only produce rapid information but also an extensive communication. This flow of communication is in progress every time. Anderson's work 
is probably relevant in his time when he stated that the objects of media attachment are faceless and anonymous. However through the development of technology, they are neither faceless nor anonymous anymore. They recognize each other's names and faces from the photographs they share and the names they cite in their profiles. This fact is articulated by Merlyna Lim in her essay, Life Is Local in the Imagined Global Community: Islam and Politics in the Indonesian Blogosphere. She proposed another term to describe this society; it is conversed community. She argued that "unlike in the imagined community where its members are faceless, in this 'conversed community', its members know each other by name" (2012: 137). However whether flow of information or communication, faceless or not is not an important concern sinceall of them are strategic means to stimulate globalization.

Based on the case, the fact is found, there is a vigorous argument that globalization gives consequences further than what 'imagined community' and 'conversed community' once conceived. Those two prominent notions were obsolete and no longer relevant to represent the condition of our society today. Another term is proposed to describe the more contemporary reality; it is the atomized society.

It is atomized because the people are split into divisions. Each division, which might still shatter into smaller clusters, has a sense of fraternity limited only to their own group. They are not hesitant to risk everything to defend their own cluster's status and dignity. Meanwhile on other side, they are also fond of making demarcatic social lines that function as distinguishing sign between them and the others. The notion of 'atomized' here indicates not only two opposite divisions of the world, but many others divisions also existed outside the two. The concept of lyan 
is consumed broadly in every atom of society. There is almost impossible to find a sense of universality that able to accommodate the whole divisions.

To delineate the notion of 'society', this paper followed Ferdinand Tonnies' argument. Tonnies in his book, Community and Society (Gemeinschaft und Gesellschaft), used Community (Gemeinschaft) to describe the typical of old human order and Society (Gesellschaft) to describe the typical of new order. He understood Community in terms of family life. It is naturally inherited and received from generation to generation. People are bound with the common values and visions from which they formulate the social goals together. Here the social bond is still very strong since each person is honored and respected.

It is society because the bond that unites them today is contractual; it is no longer communal but purely legal. This kind of social bond is not durable as it is artificial and rationally constructed; it is not natural. Tonnies understood Society in terms of free association where every single person has a freedom to associate as well as to disassociate. Unlike in Community where the group precedes the individual, in Society is vice versa. This kind of new order is very vulnerable of disunity. By prioritizing their own egos and interests, people will care of no body beside them own selves. They were already separated among the humanmade uniting factors. This term is more relevant to depict the more recent condition of today's reality.

In this type of society, gender identity is among those social categories frequently constructed in order that, consciously or unconsciously, to foster its pragmatic establishment. Unlike feminist movement, this community takes some complex and multiple agendas along with their gender exclusivity. Unlike religious congregation, they bring also some socio-economic and political issues into 
their discussion. The next section will specifically address the case in point by exploring LISMA as one of women communities in Yogyakarta that is representing this society.

\section{LISMA: Where is the Position of Women?}

In 2015, according to Asosiasi Penyedia Jasa Internet Indonesia (APJII) and Pusat Kajian Komunikasi Universitas Indonesia (UI), the internet users in Indonesia are dominated by teenagers and women (Maulana, 2015). At the same year, Pew Internet Project explored the difference between men and women on how they are using the internet and what they are mostly accessing. Their research revealed that women commonly use the internet for getting instructions from online maps, information about health problems, and the most surprisingly to find religious literacy and insight in order to fulfill their spiritual quest (Zaenudin, 2018). In the context of this research through interview, they are quite satisfied with the content of religious sermon preached by their 'imagined religious leader' (ustadz). Some of them are members of faith-based women organization, namely Lingkar Studi Mahasiswi Muslim Peduli Negeri (LISMA), but others are only participants of several agendas organized by that organization.

Unfortunately, many difficulties were found when attempting to figure out the LISMA's profile. Of course, it has many social media such as Instagram and Facebook that full of their agenda's endorsement, but then it gave no any literature that might reveal about its historical background. It even does not have any official website to which a researcher or scholar can refer as an elementary information. Lacking of those kinds of online resources, the construction of the argument was based on the informal interview with some of its members and participants. During the conversation, it was recognized about three exclusive 
natures of the community that might help explaining why it is tempting and convincing to diagnose them as suffering some elements of atomized society:

\section{a. Gender Exclusivity}

First, this community is very exclusive as its membership is limited only for Muslimah (Muslim women). Some of the events they organized such as seminar and workshop are opened only for Muslimah by citing "muslimah only" or "khusus akhwat" in the posters and pamphlets that they massively distributed through their social media. It means that if you are highly interested to join this community and its agenda, at least you have to fulfill these basic requirements; woman and Muslim. In fact, these identities, particularly the former one, are viewed as a divinely given by means that we cannot even choose to be born as a man or women. However, in order to be fair, this exclusivity might still be unequivocally understood as long as they set the reasons of their exclusivity and the agenda they organize by grounding on religious and feminist motives. Unfortunately, that is not the case, as to instead of restricted the topics of its agenda into feminine or religious affairs as the community's name refer to, they are mostly discussing about general discourses, which are academically available to be studied by everyone, regardless of their gender and religious identity.

Conversely, in terms of institutional and regional background of its members, they are multiply diverse. The members are coming from different regions all across Indonesia to studyat various prestigious universities in Yogyakarta, ranging from UGM (Gadjah Mada University), UNY (Yogyakarta State University), UAD (Ahmad Dahlan University), UMY (Muhammadiyah University of Yogyakarta), UII (Islamic University of 
Indonesia), UIN (State Islamic University) Sunan Kalijaga in which its leader along with its dominant members are known to take a degree, and other relatively small universities. Once in a week, they enthusiastically get on together to have a routine discussion by inviting an informal speaker to start the discussion. The only possible explanation for these contradicting features is that it might be seen as one of their attempt to broaden the scope of their membership without overstepping the boundary of their exclusive traits that they have formulated in the first stage. By understanding this pattern of the community, it is only women who vulnerably have the opportunity to help them in promoting their atomistic visions.

\section{b. Ideological Exclusivity}

Second, this community is a local division of its prime organization, namely Back to Muslim Identity (BMI) that is likewise hard to detect. Drawing on the name and its movement on media, It can be drawn a conclusion that this kind of organization is one of many ways of how Muslim responds to the globalization that, from their point of view, brings a lot of multi-identity effect. Notwithstanding its aforementioned beneficial features, the global phenomenon is suspected of concealing negative values among of which often cited in their social media posts are liberalism, LGBT, free sex, and democracy. The latest is seemingly most repulsive for them as they present five reasonsthrough a very brief video of why the idea should be repudiated. By following their way of thinking, let me shortly come to them in a single following paragraph:

First, the system is formulated by weak and limited human brains. We can imagine how if this human-made product is used to regulate a great number of human population. Consequently, the truth will be monopolized 
only by the majority powerful society. Secondly, it disunites Muslim community. Every single democratic countryis led by its authoritative head of states as a result of which Muslim are nowadays divided into more than 57 countries. The argument on which the second is based is taken from one of hadith saying, "If there are two caliphs then kill the last of them." It basically argues that having more than one leader is disallowed in Islam. Thirdly, it is not correspond to the aims of human creation. This is because, in democracy, an obedient to a leader is deemed as a sin, rather than religious service on the ground that the leader does not implement sharia, which is God's law. In fact, one of among the goals for which human being is created is to worship God such as expressed by one of Qur'anic verse, “And I (Allah) created not the jinn and mankind except that they should worship Me (Alone)" (Adz-Dzariyat: 56). Fourthly, it is historically not recognized in the period of Prophet and His companions. In Islam, what is performed by Muslim should find its basis in Prophetic tradition otherwise it is bid'ah (heresy) and every bid'ah is proscribed. Fifthly, it has failed to create civil prosperity. Instead, it often produced authoritarian, repressive, and promise-broker leaders.

There is no arguments against those arguments since it is not the concern of this paper, for sure. The concern is that the belief that such modern values will gradually reduce their religious identity as Muslim of which they are very fearful. Starting from this anxiety, fundamentalist movement was normally born as a reaction against liberalistic forces of globalization (Beyer, 2015:269). Unlike the first character, this is definitely not divinely given by means that we can freely choose to whom we are supposed to be ideologically associated but, however, it does not necessarily clip away its 
atomistic feature by considering that this cause is even more divisive than gender differences. Here is exactly where the sense of exclusivity was started that later on lead to atomized society. Up to this point, they have been socially and ideologically isolated themselves.

\section{c. Political Exclusivity}

Third, this community is not only focusing on religious discourse but also on political issues. Their involvement in political issues is not something relatively new as they have conducted many political campaigns and demonstration to criticize several policies issued by government. They are among those who are strongly rejected Perppu Ormas (the regulation in lieu of law on mass organization) as they believed that this is a product of anti-Islam government. They rejected the Two-state solution by United Nations (UN) to the Israeli-Palestinian conflict as they denied recognizing Israel as a state at all. To manifest their rejection practically, they joined a massive rally of what so called "Aksi Bela Palestina (Defending Palestine Action)" co-organized by Islamic organizations in Titik Nol Malioboro, Yogyakarta. They organized an online discussion particularly discussing the regulation under the topic "Mewaspadai Racun di Balik Madu RUU PKS (Keep alert to the poison behind the sweet of RUU PKS).

In some forums, they were discussing very much related to revival of the very idea of khilafah (Islamic state) one of which is an online discussion entitled "3 Maret 1924: 85 Tahun Umat Islam Hidup Tanpa Khilafah (March 3, 1924: 85 Years Muslim Live without Khilafah) by inviting a woman activist of BMI DIY, Rahmadinda Siregar, as a speaker. In the prolog, it is argued that the moment is a very tragedy for Muslim world on the grounds that after the collapse of khilafah system they 
have no more shield to protect them. This situation was aggravated by the serious division of Muslim countries into more than 50 nation states by which they are easily dictated and colonialized by imperialist Western powers. Beforehand, the similar discussion was organized offline placed at the veranda of Convention Hall, UIN Sunan Kalijaga, by having two woman speakers who are an alumnus of the university and an undergraduate student of UGM. This discussion is kind of their symbolic foreground of Syrian conflict following a long-standing conflict between Iran and Palestine. They displayed very provocative narratives in framing the conflict as to ignite Muslim anguish and get them involved in jihad, at very least in what they called jihad soghir (little jihad), which is praying for the oppressed Muslim.

Unconsciously, their movement might lead them into a political segregation as well. From that, they are no longer secluded merely on religious affairs but also on ideological as well as political affairs. Those exclusive features show also the vulnerability of women as they targeted by the community exclusively. This fact is eventually going to approve this thesis; atomized society. Women is potentially involved as an agent for they are known as dominantly users of internet through which they are inclined of making social exclusion at least by interpreting the case in point. Through the help of social media, those three natures are potentially elevated up to the level of divisive.

After all, it is however important to emphasize that LISMA is just one of few existing faith-based women communities in Yogyakarta where mostly are actually inclusive and open for everyone. Srikandi Lintas Iman (SRILI), for instance, is also a fresh faith-based women community that is massively using social media to expose their routine agenda. Unlike LISMA, it is very 
easy to recognize this community by visiting its website or coming to its headquarter immediately. In spite of based on faith and gender, their programs are open to everyone from any religious, ethnic, and gender background. Unfortunately, none of those communities is representing a purely religious-based community, Islam in particular, to discuss its tenets through which young Muslim women in Yogyakarta are expected to learn the religion; they are only dealing with mundane matters such as art (FAB Photography Club and Lembaga Teater Perempuan/Women Theater Foundation), local wisdom (Komunitas Perempuan Berkebaya/Traditional Clothed Women Community), entrepreneurship (Perempuan Punya Karya/Women Enlightenment Community), et cetera.

In fact, the presence of such community is crucially necessary as we recently witness a religious upsurge among women in Yogyakarta such as experienced by one of my anonymous respondent. She claimed that LISMA is the only women community within which she expects to learn Islam although she has to be lately disappointed of the fact that the community exceeds the course up to dealing with political as well as ideological discourses.Even if there is might be a number of such an expected community, so to speak, but they are not familiar to them. Consequently, this vacancy has been timely plugged by LISMA by outwardly declaring itself as religiously discussing Islamic way of life and inviting many young women in Yogyakarta to eagerly join in. Therefore, to avert a generalist logic, this discussion will be ended by arguing that this is only because other women communities are not this paper concern since only focusing on the multipolar effect of globalization on women represented by this community. 


\section{Conclusion}

Globalization as a natural process, it gave a lot of effect, both negative and positive. Insofar as it is related to those processes, globalization grants some benefits for women. In addition to those beneficial effects, it should be taken into account as well as to how those processes are also beneficial for women to mobilize a women mass or even movement through which their internal solidarity is strengthened. In this regard, LISMA is proposed as one of among many women communities in Yogyakarta to represent the case in point by reckoning with their active promotion of their exclusive agendas. This is through the help of media that they somehow went further by excluding another element of society as they became more and more exclusive to particular identities. The idea of 'atomized society' is used to reflect their exclusive features, as they do not use the media simply to access information (imagined community) or have a conversation (conversed community), but rather to elitize themselves up to not everyone can access them and their activities. This idea is drawn on the three exclusive traits they are possessing; gender exclusivity, ideological exclusivity, and political exclusivity. Women as a group deliberately targeted by the community are vulnerable to such atomistic effects, besides thinking as well that they are the most internet users and mostly access it to consume religious information to forward them back vastly through their social media.In the case presented, it is obvious that they used the media exclusively to strengthen their religious identity. Hence, this paper strongly argued that globalization through media and women religiosity has fragmented human into pieces. It makes the project of human unity more unlikely to be realized since the society has been atomized. 


\section{REFERENCES}

Anderson, Benedict, 1991, Imagined Communities: Reflections on the Origin and Spread of Nationalism, London, England: Verso.

Ayu, Miranda R, 1997, "Muslimah di Era Globalisasi," in Membincangkan Feminisme: Refleksi Muslimah atas Peran Sosial Kaum Wanita, Bandung: Pustaka Hidayah.

Baum, Gregory, 1975, Religion and Alienation: A Theological Reading of Sociology. New York: Paulist Press.

Beyer, Peter, 2015, Religion out of Place? The Globalization of Fundamentalism. The Routledge International Handbook of Globaliation Studies, United Kingdom: Routledge and CRC Press.

Giddens, Anthony, 2000, Runaway World: How Globalization Is Reshaping Our Lives. New York: Routledge.

Horkheimer, Max, 1972, Critical Theory: Selected Essays. New York: Continuum Publishing Company

Huntington, Samuel P, 1996, The Clash of Civilizations and the Remaking of World Order, New York: Simon \& Schuster.

Lim, Merlyna, 2012, "Life Is Local in the Imagined Global Community: Islam and Politics in the Indonesia Blogosphere" Journal of Media and Religion, 11, 127140.

Maulana, Adhi, (2015, 26 March). 'Pengguna Internet Indonesia Didominasi Remaja \& Wanita'. Liputan 6.

Sen, Amartya, 2002), "How to Judge Globalism" The American Prospect: Winter 2002: ProQuest pg.A2. 
Smith, Jane I, 1987, "Islam," in Women in World Religions, edited by Arvind Sharma, New York:State University of New York Press

Tonnies, Ferdinand, 2001, Community and Society, edited by Jose Harris, Cambridgeshire: Cambridge University Press.

Vasquez, Manuel A. and Marquardt, Marie Friedmann, 2003, Globalizing the Sacred: Religion across the Americas, New Jersey: Rutgers University Press.

Zaenudin, Ahmad, (2018, 19 February). 'Beda Perilaku Lakilaki dan Perempuan dalam Menggunakan Internet'. Tirto.id 